\title{
PERFORMANCE EVALUATION OF BUMN PERKEBUNAN AFTER RESTRUCTURING
}

\author{
Dian Andrayani ${ }^{*}$, Marimin $^{* *}$, and Sahara $\left.{ }^{* * *}\right)$ \\ *) School of Business, IPB University \\ Jl. Raya Pajajaran, Bogor 161515 \\ **) Department of Agro-Industrial Engineering, Faculty of Agricultural Technology, IPB University \\ Jl. Meranti, IPB Darmaga Campus, Bogor 16680 \\ ${ }^{* * *}$ Department of Economic, Faculty of Economics and Management, IPB University \\ Jl. Agatis, IPB Dramaga Campus, Bogor 16680
}

\begin{abstract}
SOE's (BUMN) restructuring is one of the government's efforts to improve the performance and competitiveness of companies. However, this doesn't necessarily occur due to differences in the challenges of change in each SOE. Therefore, to understand the impact of restructuring research on the performance evaluation of BUMN Perkebunan is needed. Data collection was carried out in May-November 2017 at Holding Perkebunan Office, Jakarta. The data used is secondary data in the form of company financial statements for the period 2012-2016. The data was processed by EVA methods to determine the economic value added to the company. The results showed that the highest and the only positive EVA was achieved before the restructuring, namely in 2012. After that, the EVA continued to decline and was at its lowest point in the third year after restructuring, namely in 2016. This decrease occurred due to the influence of components that support EVA, such as corporate income and expenditure, beta ( $($ ), return market (rm), risk-free ( $\mathrm{rf}$ ), and the capital structure. To increase the EVA, the company has to make improvements by increasing the income, reducing the expenditure, reviewing the interest rate (rf), and keeping the proportion of capital structure.
\end{abstract}

Keywords: Restructuring, BUMN Perkebunan, Performance Evaluation, EVA

\begin{abstract}
Abstrak: Restrukturisasi yang terjadi pada BUMN merupakan salah satu upaya pemerintah untuk memperbaiki kinerja dan meningkatkan daya saing perusahaan. Namun, hal ini tidak serta merta dapat terwujud karena adanya perbedaan tantangan perubahan pada masing-masing BUMN. Oleh karena itu, guna melihat dampak kemajuan dari langkah restrukturisasi yang diambil, dilakukan penelitian mengenai evaluasi kinerja BUMN Perkebunan. Pengambilan data dilaksanakan pada bulan Mei-November 2017 di Kantor Holding Perkebunan, Jakarta. Data yang digunakan adalah data sekunder berupa laporan keuangan perusahaan selama periode tahun 2012-2016. Data tersebut selanjutnya diolah dengan teknik EVA untuk mengetahui nilai tambah ekonomi yang dihasilkan perusahaan. Hasil penelitian menunjukan bahwa nilai EVA tertinggi dan satu-satunya yang positif dicapai pada masa sebelum restrukturisasi atau sebelum terbentuknya holding perkebunan, yakni di tahun 2012. Setelah itu, nilai EVA terus menurun dan berada di titik terendahnya pada tahun ketiga setelah restrukturisasi, yaitu tahun 2016. Penurunan ini dapat terjadi karena adanya pengaruh sejumlah komponen pendukung EVA, seperti pendapatan dan pengeluaran perusahaan, beta sektoral ( $\beta$ ), return market ( $\mathrm{rm})$, risk free ( $\mathrm{rf})$, serta proporsi struktur modal. Untuk meningkatkan kembali nilai EVA, maka perusahaan harus melakukan perbaikan, antara lain dengan meningkatkan pendapatan, menekan pengeluaran, melakukan kajian mengenai tingkat suku bunga (rf), serta menjaga struktur modal agar tetap proporsional.
\end{abstract}

Kata kunci: Restrukturisasi, BUMN Perkebunan, Evaluasi Kinerja, EVA

\footnotetext{
${ }^{1}$ Corresponding author:

Email: dandrayani@yahoo.co.id
} 


\section{INTRODUCTION}

One of the contributions of SOE in the Indonesian economy can be seen from the financial aspect, namely the company's revenue and profit. In 2010-2014, SOE revenue experienced growth with a compound annual growth rate (CAGR) of $10.58 \%$ or an increase of $75.8 \%$. It was followed by an increase in net income by $49.5 \%$ (Ministry of SOE, 2015). In general, the ability of Indonesian SOEs to produce this profit is considered good, based on the statement from Lestari and Sugiharto (2007), which states that a healthy ROA value for the company is more than $2 \%$. Meanwhile, the healthy NPM value for the company is more than 5\% (Sulistyanto and Midiastuti 2002). However, when compared to the SOEs of neighboring countries, namely Singapore and Malaysia, the financial performance produced by Indonesian SOEs is still relatively low. The Managing Director of the University of Indonesia Institute of Management (LM UI) explained that in a comparative study conducted using 2014 data, among the 20 Indonesian SOEs that had an IPO with Temasek (Singaporean SOE) in charge of 15 companies, as well as Khazanah (Malaysian SOE) which oversees 24 companies, it was obtained that the indicator of profit margin 20 Indonesian SOEs was lower than Temasek and Khazanah with a value of $15.57 \%$ respectively; $19.48 \%$; and $40.4 \%$ of total revenue .

The lack of optimal financial performance produced by Indonesian SOEs is inseparable from the various problems that surround it. These problems can come from internal and external companies, such as limited internal funds so that they depend on foreign funds that have costs high; corporate management system which includes the form and structure of company ownership, effectiveness of supervision, and capability of the manager; business competition dynamics; and institutional factors (Santoso, 2007; Sagala, 2007). Siswaji (2013) further explained that institutional factors, including those related to legal aspects, political, and social, are problems that are hindering the implementation of the strategy in realizing the objectives of SOE as a corporation. Given these various problems, the government needs to make practical efforts to improve the performance and competitive advantage of SOEs. These efforts can take the form of restructuring, which includes sectoral and corporate restructuring (increased intensity of business competition, structuring functional relations between the government as regulator and SOEs as business entities, and internal restructuring); or privatization (Law No. 19 of 2003).

Privatization is one of the mechanisms of organizational change that is most often chosen by many SOEs in the world because this mechanism makes it easy for companies to obtain additional capital directly. However, privatization has advantages and disadvantages that must be considered, especially if it is carried out on SOEs that manages vital objects/commodities in the country (Chang, 2007; Konings et al. 2005). In contrast to privatization, a restructuring mechanism is generally used to reform a sector or company directly, so that this mechanism has a broader and comprehensive scope. Several types of restructuring seen from the focus of its activities are legal restructuring, financial restructuring, operational restructuring, and physical restructuring (Kennedy and Jones, 2007).

Restructuring by simplifying the number and formation of a holding company is an effort to improve the performance of SOEs recently undertaken by the government. One of the SOE groups that experienced it was plantations, which was reduced by thirteen units and changed its status to holding plantations. The holding plantation is classified as the company that is most expected to improve its performance because it oversees the most subsidiaries. In addition, the holding plantation has the largest plantation SOE in Asia that holds a lot of potentials, such as the financial aspect in the form of projected contributions to state revenues that will increase by $15 \%$.

However, the performance improvements expected from Plantation SOEs after the restructuring so far have not shown significant results, even though this strategic step has entered the third year of implementation. Recorded in 2015, holding plantation still posted a loss of 613 billion rupiahs (PTPN III, 2016). It is different from the restructuring process that occurred in the cement SOE group, which in the third year of the formation of PT. Semen Indonesia (holding cement), has succeeded in acquiring a Vietnamese cement company, namely Thang Long Cement Vietnam . This condition confirms that it is necessary to conduct an evaluation of the holding plantation because the choice to carry out a restructuring does not necessarily have a direct positive impact on the company. 
Evaluation as a method has various forms of implementation, one of them is the performance measurement approach. In the context of companies that have undergone restructuring, such as holding plantation, a performance measurement approach can help stakeholders in assessing achievements and getting to know the company's potential, as well as optimizing the use of resources. This approach is also flexible because it can be done before (ex-post) or after (ex-ante) the company's goals are achieved (Khakee, 1998). Thus, an overview can be obtained about how certain facilities or instruments work, as well as views related to forms of performance management, to overcome problems and obtain good achievements (Stame, 2004; Hildebrand and McDavid, 2011).

In measuring performance, indicators that are commonly used by companies, including holding plantation, are the financial aspects. It can be seen from the company's annual report that it always includes financial achievements. However, the use of financial aspects as a single indicator of performance measurement is seen by some experts as inadequate because it is not comprehensive. This is as stated by Suratno (2005); Young and O'Byrne (2000) that the measurement of company performance using financial indicators often does not reflect actual performance, because it is unable to show management's achievements in encouraging activities or strategies that add value to the company's economy, or remove activities that damage the value of the company. Performance measurement with financial aspects is also less relevant because it tends to focus on adding profit but not the value of the company. Based on this explanation, the ideal performance measurement is not enough if only based on financial indicators, but also needs to be seen from economic indicators. Because these indicators take into account the company's ability to create economic value added. Moreover, this indicator can also correct the weaknesses of the financial indicators, namely by taking into account the cost of capital in place of the risks and be able to identify the driving activity value (value driver) companies from other aspects beyond the financial aspects (Singgih, 2008; Utomo, 1999). Based on this description, it is necessary to conduct research related to the performance of Plantation SOEs before and after becoming a plantation holding.

Generally, this study aimed to evaluate the performance holding of SOEs Plantation. Specifically, this study aims to analyze the performance of Plantation SOEs before becoming a holding and after becoming a holding.

\section{METHODS}

This research uses the descriptive method, which aims to describe the performance of holding plantation. Research data collection was carried out at the Office Holding Plantation, located in Agro Plaza Building, 15th Floor, Jalan HR. Rasuna Said Kav. X2 / 1, Kuningan, Jakarta, and at the Office of PT. Kharisma Nusantara Joint Marketing (KPBN) on Jalan Taman Cut Mutiah No. 11 Kebon Sirih, Menteng, Jakarta. Performance measurements before becoming a holding were carried out on fourteen plantations SOEs, for the 2012-2013 operational year. Meanwhile, performance measurement after becoming a holding was carried out for the 20142016 operational year. The time of data collection takes place during May-November 2017.

This study used secondary data, which includes the financial statements (balance sheet and income statement) of PTPN I-XIV in 2012-2013 as well as the 2014 plantation holding financial statements up to 2016. The secondary data is obtained from each company's annual report. The data is then processed using EVA techniques and analyzed descriptively. EVA analysis is used to determine the performance of state-owned estates in producing economic value in the period before and after becoming a holding. EVA provides an overview of management and investors about the company's ability to cover the cost of capital (cost of capital) and bring (shareholder value). The steps to get EVA value is shown in Table 1. The research framework is shown in Figure 1.

\section{RESULTS}

\section{Performance Analysis of Plantation SOEs Before and After Becoming a Holding}

The SOE Plantation Group or PTPN I-XIV was formally formed in the 1990s, to be exact in 1996 . The transformation of Plantation SOEs into Holding Plantation, occurred approximately eighteen years later, namely 2014. The idea of the transformation arose because PTPN's performance considered not optimal, both in terms of its establishment and its ability to compete with private plantation companies. Therefore, a restructuring mechanism is needed to improve competitiveness, a synergy between PTPN, market value, and company value. However, it must be kept in mind that the restructuring decision does not necessarily 
bring progress to the company, because there are challenges of different changes in each business sector. Therefore, it is necessary to assess the performance of Plantation SOEs before and after becoming a holding by the EVA method.

The EVA method was chosen because it is considered comprehensive in describing the creation of added value companies, both from financial and economic aspects. In addition, the method can also help companies to focus on activities that drive value. The EVA calculation in this study is based on the company's balance sheet and income statement for five years (years 2012-2016). The results of EVA calculations for Plantation SOEs in 2012-2016 are shown in Table 2.

Table 1. Steps for calculating EVA

\begin{tabular}{|c|c|c|}
\hline Steps & Formula & Source \\
\hline 1. EVA (economic value added) & $\mathrm{EVA}=\mathrm{NOPAT}-$ capital charge & Tunggal (2001) \\
\hline 2. NOPAT (operating profit after tax) & $\mathrm{NOPAT}=$ net profit afer tax + interest costs & Tunggal (2001) \\
\hline 3. Capital charge (capital to replace investment) & Capital charge $=$ invested capital $\times$ WACC & Tunggal (2001) \\
\hline 4. Invested capital (capital invested) & $\begin{array}{l}\text { Invested capital }=\text { total of debt and equity } \\
\text { - trade debt - accrued costs - tax debt - } \\
\text { customer advances }\end{array}$ & Tunggal (2001) \\
\hline 5. WACC (capital costs weighted average) & $\mathrm{WACC}=$ weke + wdkd & $\begin{array}{l}\text { Prasetyo and Budiyanto } \\
\text { (2014) }\end{array}$ \\
\hline 6. ke (cost of equity) & $\mathrm{ke}=\mathrm{rf}+\beta(\mathrm{rm}-\mathrm{rf})$ & $\begin{array}{l}\text { Prasetyo and Budiyanto } \\
\text { (2014) }\end{array}$ \\
\hline 7. rm (market rate of return) & $\begin{aligned} \mathrm{rm}= & \text { IHSGt }- \text { IHSGt-1 } \\
& \text { IHSGt-1 }\end{aligned}$ & $\begin{array}{l}\text { Prasetyo and Budiyanto } \\
\text { (2014) }\end{array}$ \\
\hline 8. $ß$ (irrevocable risk) & $y=\beta x+$ residual & Naibaho (2012) \\
\hline 9. kd (debt costs) & $\mathrm{kd}=\mathrm{rd}(1-\mathrm{t})$ & Pahlevi (2017) \\
\hline 10. rd (lending rate) & $\mathrm{rd}=$ interest expense long term debt & $\begin{array}{l}\text { Prasetyo and Budiyanto } \\
\text { (2014) }\end{array}$ \\
\hline
\end{tabular}

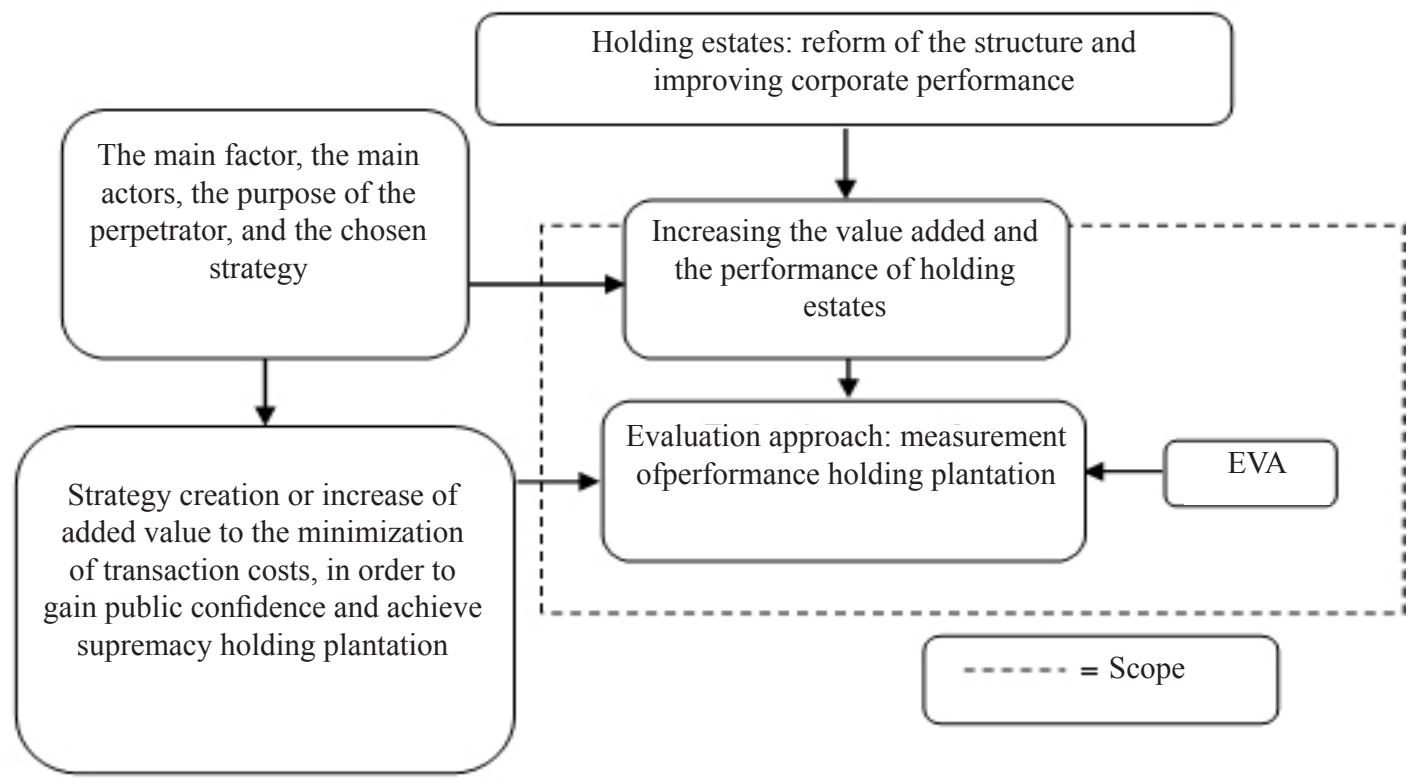

Figure 1. Research framework 
Table 2. The results of EVA calculations for SOE Plantation in 2012-2016

\begin{tabular}{cccccc}
\hline \multirow{2}{*}{ Year } & & \multicolumn{3}{c}{ Variable (Million Rupiah) } & \multirow{2}{*}{ WACC (\%) } \\
\cline { 3 - 5 } & & EVA & NOPAT & Capital Charge & \\
\hline Before becoming a holding & 2012 & 3257805.28 & 4519998.47 & 1262193.19 & 2.67 \\
& 2013 & $(170828.61)$ & 3315076.16 & 3485904.77 & 6.52 \\
& 2014 & $(251744.59)$ & 3045963.88 & 3297708.47 & 5.76 \\
After becoming a holding & 2015 & $(880448.12)$ & 1900791.11 & 2781239.23 & 2.77 \\
& 2016 & $(3014799.28)$ & 1815791.85 & 4830591.13 & 4.73 \\
\hline
\end{tabular}

Table 2 shows the results of EVA calculations before holding (2012-2013), the transition or restructuring period from PTPN to holding (2014), and the period after becoming holding (2015-2016). The results of these calculations showed that the EVA value of Plantation SOEs tends to decrease from year to year. In the period before the formation of the holding, precisely in 2012, the EVA value of Plantation SOEs reached IDR3,257,805,280,000 or the highest in the 2012-2016 period. It means that the SOE has managed to record a higher profit value than the value of capital, thereby providing added value to the company's wealth. In 2013, the EVA value of Plantation SOEs had begun to decline. The decrease in this year is considered significant because the biggest during the 2012-2016 period was negative IDR $170,828,610,000$ or decreased by IDR3,428,633,890,000. It was caused by a decrease in NOPAT and a large increase in WACC. The increase in WACC, in particular, has an impact on increasing the capital charge (capital to replace investment) used by the company. If it is not anticipated, the decrease in EVA value can cause several losses to Plantation SOEs, including the potential loss of profit of at least 3.2 trillion rupiahs and an indication of the company's inability to compensate investors, because the profit value is lower than the value of capital. These things are then believed to encourage the government to restructure the Plantation SOEs.

During the transition period (in 2014), EVA was recorded to have decreased, although itwasnot as big as the previous year, which became negative IDR251,744,590,000 or decreased by IDR80,915,980,000. This condition occurred due to a not too large drop in NOPAT and the presence of WACC reduction, thereby reducing capital charges. However, it still indicates that there has been no improvement in performance at Plantation SOEs. Especially this year, the restructuring step has been carried out. However, this condition is understandable because the restructuring itself was only carried out in October 2014 or three months before the end of 2014, so the benefits cannot be seen significantly.
In the period after the formed holding was (in 2015), the decline in the value of EVA again occurred with a greater value than the previous year (reaching almost eight times that of 2014), which became negative IDR880,448,120,000 or decreased by IDR628,703,530,000 This decline was mainly due to a significant decrease in NOPAT (the second largest in the 2012-2016 period). The WACC can be suppressed by the intervention of the government in the form of the addition of state capital participation to PTPN III as the parent holding, which is ratified through PP No 135 the year 2015. It directly changes the proportion of capital structure, especially equity, and reduces capital charge. In the second year after the formation of the holding (in 2016), the decrease in EVA value did not stop until it made it at the lowest value for the period 20122016, which became negative IDR3,014,799,280,000 or decreased by IDR2,134,351,160,000. The decrease happened again due to an increase in WACC, which increased capital charges. When further observed, the increase in WACC indirectly indicates the tendency of companies to rely on debt. It can be observed from the proportion of debt in the capital structure of the company that has increased again. This condition is worrying because it signifies that the company is not stable after changing its status and has not fulfilled the basic idea of forming a holding company, which is to create added value, increase company competitiveness, and resolve conflicts between SOEs in similar industry sectors (Pranoto and Makaliwe, 2014).

\section{Factors Affecting EVA}

From the performance analysis, it is shown that the EVA value is influenced by several factors, including NOPAT and WACC. The NOPAT and WACC are inseparable from the influence of several supporting components, such as company income and expenses, sectoral beta ( () , market return (rm), risk-free (rf), and the proportion of capital structure. 
The supporting components that influenced the NOPAT factor are the company's income and expenses. From the revenue side, it is understood that an increase in 2013-2014 was $3.13 \%$ and $2.46 \%$. The increase was respectively due to an increase in the number of sales and selling prices of palm oil. However, the increase in revenue was also accompanied by an increase in expenditure with a greater percentage, particularly in other operating expense items and financial expenses, which were $106.78 \%, 10.45 \%, 8.85 \%$, and $37.18 \%$ respectively. In 2015-2016 a slightly different thing happened, namely a decrease in company revenue by $-8.32 \%$ and $-6.39 \%$. Each of the decreases was caused by a decrease in selling prices and total sales of palm oil. The decline in prices occurred because of the revival of environmental issues related to oil palm management in Indonesia, so the demand for palm oil declined. The condition was exacerbated by the decline in palm oil production caused by weather anomalies in the form of drought (El Nino), which triggered fires in several oil palm fields. The impact of El Nino continues in 2016, so the company's revenue continues to decline. From the expenditure side, there was an increase in 20152016 at the same post as the previous two years, namely other operating expenses and financial expenses. The increases were respectively $60.46 \%, 35.78 \%, 20.05 \%$ and $21.13 \%$. If further observed, there is an imbalance between revenues and company expenses. Corporate expenses tend to increase every year due to an increase in other operating expenses and financial expenses. These conditions accumulatively make NOPAT companies continue to decline. The decline in NOPAT of the company in $2013-2016$ was $-26.66 \%,-8.12 \%$, $-37.60 \%$ and $-4.47 \%$.

The increase in expenditure on financial expense items, including interest expense, was indirectly affected by the component rf reflected by the Bank Indonesia Interest Rate (SBI) and the increase in debt. The increase was in line with the explanation by Amalia (2006) and Daniel \& Sedana (2017) that the higher the interest rates, the more the costs or costs of interest must be paid, thereby reducing the company's profitability. However, this condition is not absolute because it depends on the debt policy that applies to every company. Mulianti (2010) states that an increase in corporate debt will increase liabilities, such as interest expenses. The increase in interest expense is not infrequently greater than the tax savings obtained by the company. Thus, the company's interest expense will increase especially when there is an increase in debt and an increase in SBI. It is similar to the conditions in 2015 and 2016 (the year with the largest and smallest percentage decline in NOPAT). In 2015 , there was a decrease in the addition of long-term debt (up 9.86\%), but this year's SBI rate was high, at $7.52 \%$, so the company's interest expense increased. Meanwhile, in 2016 there was a decline in SBI to 6\%, but due to an increase in long-term debt increase (up $12.98 \%$ ), the company's interest expense continued to increase.

The influence of SBI was not only affected the NOPAT factor, but also the WACC factor along with several other components that influence it, such as $\beta, \mathrm{rm}$, and the proportion of capital structure. It is the same as what happened in 2012 and 2015. In 2012, SBI values were the lowest for the 2012-2016 period, which was 5.77\%; the value of $\beta$ and rm can be said to be good because they are positive, namely 1.23 and $1.08 \%$ respectively; and proportional capital structure, which is $50.6 \%$ debt and $49.4 \%$ equity. These conditions make the lowest WACC value during 2012-2016, which is $2.67 \%$. In 2015 , as previously discussed, the SBI value could be said to be high, namely $7.52 \%$; the value of $\beta$ and $\mathrm{rm}$ can be said to be unfavorable because it is less than one and negative, namely 0.84 and $-0.98 \%$ respectively; however, the proportion of capital structure is greater than equity, which is $60.5 \%$ and $39.5 \%$. It makes the second-lowest WACC value during 2012-2016, which is $2.77 \%$.

From the explanation, it was observed that the relationship between the supporting components of WACC factors, especially SBI, $\beta$, and rm. It is in line with the explanation of Sudiyatno (2010) that the interest rate has a positive influence on the systematic risk, which in this study is represented by the value $\beta$. This condition implies that when SBI is low (as in 2012), the systematic risk decreases and or the value is $\beta$ more than one so that the market (returns are rm) and company positive. Even the company's rate of return can be greater than the market rate of return. However, the opposite also applies, namely, when SBI is high (as in 2015), the systematic risk increases and or the value is $\beta$ less than one, so the market return ( $\mathrm{rm}$ ) or the company is not good or negative. Furthermore, the company's rate of return can be lower than the market rate of return. 
In these conditions, it is not uncommon for the proportion of capital structure to determine the final value of WACC. This is as stated by Pahlavi (2017) that capital structure is the composition of funding sourced from debt and equity. Therefore, companies need to direct it to be optimal. There are several ways that companies can do to achieve the optimal value, for example, by paying attention to increasing debt because of the potential to cause financial distress, financial growth and profit growth as planned to avoid default (unable to pay), and debt restructuring or increasing the company equity. From this presentation, it is understood that debt influences more dominant than equity in the capital structure. Therefore, companies need to be careful in issuing policies related to debt. The use of debt to a certain extent can be considered reasonable, especially in the business world. However, there are maximum limits that companies must pay attention to, for example when marginal income from present value tax savings equals marginal cost from bankruptcy costs or when debt risk is greater than benefits (Sudibyo, 1997; Mulianti, 2010). Thus, a better WACC value can be generated, especially when the company's capital structure is proportional (balanced between debt and equity).

\section{Managerial Implications}

Restructuring as a mechanism to improve the performance of SOE can produce different impacts on the company. This is due to the challenges of each change in each business sector. In the case of stateowned plantation companies, the restructuring did not necessarily have a positive effect. This condition can be seen from the results of a performance evaluation using EVA techniques during the period 2012-2016. It is known that the EVA value of Plantation SOEs tends to decrease from year to year. The largest and only positive EVA value was recorded in 2012 (before restructuring/ formation holding). After that, EVA continues to decline until it reaches the lowest rate in 2016 (the period after restructuring/formation of holding). This indicates that the performance of state-owned estates is better before becoming a holding compared to after becoming a holding. However, this condition is not permanent because the journey of holding a plantation as a company is still relatively long. To increase EVA value again, holding plantation needs to pay attention to several supporting components, such as company revenue and expenditure, beta sectoral ( $($ ), market return (rm), riskfree (rf), and proportion of capital structure.
The company's revenue, which so far has been largely derived from the sale of palm oil, is considered insufficient to produce positive EVA. Therefore, companies must increase their income through various methods. One way to increase the income is to develop business units, including in the downstream sector, so new sources of income are built. It is well known that the change in the status of the company into a holding plantation has led to an increase in the business and products handled. This is potential for business expansion. However, the development of oil palm as the main commodity of SOE Plantation should not be forgotten, because it is believed to have a multiplier effect a greater on company revenue. The focus of oil palm development can lead to increased productivity, more effective cropping and harvesting patterns, more efficient maintenance mechanisms, and derived products.

Meanwhile, company expenses have so far been considered inefficient, given the imbalance between income and expenses. The company's expenses tend to continue to increase, while the company's revenue tends to fluctuate (if it experiences an increase that is not as big as the expenditure item). Therefore, savings must be made so that there is no decrease in EVA's greater value. The savings can be started by evaluating other operational expenses, which are consistently increasing every year. Operational activities included in this post need to be sorted according to their importance and rebudgeted effectively. In some cases, it is also possible to write off or cut the budget for activities that are considered less important or unnecessary. Another thing that also significantly influences company expenses is financial expense and or interest expense. In this post external factors such as interest rates (rf) represented by SBI greatly affect the company's interest expense. An increase in interest rates accompanied by an increase in long-term debt will directly cause an increase in the company's interest expense. Furthermore, interest rates also have a positive relationship that is not in the same direction as $\beta$ and $\mathrm{rm}$. This means that when there is an increase in interest rates, the value of $\beta$ and $r m$ decreases. This condition will directly increase the systematic risk to the company and reduce market returns. Therefore, companies need to conduct studies on macroeconomic trends, particularly interest rates, in order to determine activities that can maintain or increase the value of EVA, especially in situations of rising interest rates. 
However, the results of the study can be of little use if they are not supported by policies governing the company's capital structure. The composition of the capital structure of holding has plantation so far been considered to be less proportionate because it tends to rely on debt. This is quite risky because it has the potential to cause defaults or financial difficulties. Therefore, it is important for companies to maintain their capital structure to remain proportional (balanced between debt and equity). This can be done including by maximizing the use of capital, especially equity, for operational and investment activities, as well as examining the urgency of adding debt and payment systems.

\section{CONCLUSIONS AND RECOMMENDATIONS}

\section{Conclusions}

Performance evaluation with EVA techniques at Plantation SOEs shows a downward trend over the 2012-2016 period. This indirectly indicates that the performance of SOE Plantation before becoming a holding is better than after becoming a holding. These conditions can generally occur due to a decrease in net income after tax (NOPAT) and an increase in the weighted average capital cost (WACC). The NOPAT and WACC factors are also inseparable from the influence of several supporting components, such as company income and expenses, sectoral beta ( () , market return (rm), risk-free (rf), and the proportion of capital structure. These components have an important role and interrelated relationships in generating EVA values. Some ways that can be done to increase the EVA value of Plantation SOEs seen from its supporting components are adding revenue, reducing expenditure to be more efficient, reviewing macroeconomic trends, especially interest rates, and maintaining capital structure to remain proportional or balanced.

\section{Recommendations}

The results showed that the EVA value is strongly influenced by the company's revenue and expenditure components, interest rates (rf), and capital structure. Therefore, companies must pay attention to things that can affect these components, both from internal and external to the company. The issue of the identified internal influencing EVA support component in this research is the failure to achive revenue growth and inefficiency of expenditure because of the company's human resources did not achieve optimal performance, as well as policies regarding capital structure which tends to rely on debt to operating activities. Meanwhile, external issues were identified influencing the supporting components of EVA in this study, including the weather, environmental issues / negative sentiment related to Indonesian palm oil, and the interest rate (rf) reflected by SBI. In general, matters originating from within the company are indeed more manageable than matters originating from outside the company. However, this condition does not mean that matters originating from external companies can be ignored, because often it is a greater influence on changes in the value of EVA supporting components. Therefore, it is necessary to study further about the activities of driving the value of the company, especially in situations that are not conducive as above. In addition, it is also necessary to study related priority strategies to develop the company and measure performance with EVA techniques in the next year period, so that each step taken by the company is more systematic and the company's progress in producing EVA can be measured.

\section{REFERENCES}

Amalia KS. 2006. Penilaian kinerja dan analisa value driver economic value added (EVA) di Bank BRI Kantor Cabang Warung Buncit Jakarta [tesis]. Bogor: Institut Pertanian Bogor.

Chang H. 2007. State-Owned Enterprise Reform [Policy Notes]. New York: United Nation Departement For Economic and Social Affairs (UNDESA).

Daniel W, Sedana IBP. 2017. Pengaruh ukuran perusahaan, suku bunga, dan struktur modal terhadap profitabilitas. E-Jurnal Manajemen Unud 6(12):6913-6931.

Hildebrand R, McDavid JC. 2011. Joining public accountability and performance management: a case study of Lethbridge, Alberta. Canadian Public Administration 54(1):41-72. https://doi. org/10.1111/j.1754-7121.2011.00160.x.

Kennedy RM, Jones LP. 2002. Options for afghanistan's state-owned enterprises: lesson of international experience [working paper]. Vienna: United Nations Industrial Development Organization (UNIDO).

Khakee A. 1998. Evaluation and planning: inseparable concepts. The Town Planning Review 69(4): 356-374. https://doi.org/10.3828/ 
tpr.69.4.3803q86489619xm7.

Konings J, Cayseele PV, Warzynski F. 2005. The effect of privatization and competitive pressure on firms price cost margins: micro evidence from emerging economies. The Review of Economics and Statistics 87(1):124-134. https://doi. org/10.1162/0034653053327603.

Lestari MI, Sugiharto T. 2007. Kinerja Bank Devisa dan Bank Non Devisa dan Faktor-Faktor yang Mempengaruhinya. Proceeding PESAT (Psikologi, Ekonomi, Sastra, Arsitek, dan Sipil); 2007 21-22 Agustus; Depok, Indonesia. Depok: Universitas Gunadarma. Vol. 2: hal. A195A201.

Mulianti FM. 2010. Analisis faktor-faktor yang mempengaruhi kebijakan hutang dan pengaruhnya terhadap nilai perusahaan (studi pada perusahaan manufaktur yang terdaftar di Bursa Efek Indonesia Periode tahun 2004-2007) [thesis]. Semarang: Universitas Diponegoro.

Naibaho O. 2012. Analisis struktur modal optimal PT. $\mathrm{X}$ [thesis]. Jakarta: Indonesia.

Pahlevi R. 2017. Analisis struktur modal optimal dan pengaruh kinerja keuangan terhadap struktur modal: Kasus PT Perkebunan Nusantara-V [thesis]. Bogor: Institut Pertanian Bogor.

PTPN III. 2016. Laporan Tahunan 2015: Meningkatkan Kinerja Melalui Transformasi Bisnis. Medan: PT. Perkebunan Nusantara III.

Pranoto T. dan Makaliwe W A. 2014. Restrukturisasi BUMN menjadi holding company.http://lmfeui. com/data/part\%203\%20majalah\%20bumn $\% 20$ 21\%20ags\%202014.pdf [4 Okt 2016].

Prasetyo D, Budiyanto. 2014. Metode EVA untuk mengukur kinerja keuangan perusahaan perkebunan di bursa efek Indonesia. Jurnal Ilmu Riset dan Manajemen 3(4).

Sagala P. 2009. Penyebaran kepemilikan saham pemerintah pada badan usaha milik negara (BUMN) untuk menciptakan perusahaan yang sehat dan efisien [disertation]. Medan: Sumatera Utara.

Santoso SP. 2007. Privatisasi: penerapan nasionalisme pengelolaan BUMN. https://muhariefeffendi. files.wordpress.com $/ 2007 / 11 /$ privatisasi penerapan-nasionalisme-pengelolaan bumn.pdf [9 Sept 2016].

Singgih ML. 2008. Pengukuran Kinerja Perusahaan Dengan Metode Economic Value Added. Prosiding Seminar Nasional Manajemen Teknologi VIII; 20082 Agustus; Surabaya, Indonesia. Surabaya: Institut Teknologi Sepuluh November. Hal: A-21-1 - A-21-8.

Siswaji B. 2013. Pengaruh institusi dan strategi terhadap kinerja badan usaha milik negara (BUMN) [disertasi]. Bogor: Institut Pertanian Bogor.

Stame N. 2004. Theory-based evaluation and types of complexity. Evaluation 10(1):58-76. https://doi. org/10.1177/1356389004043135.

Sudibyo B. 1997. Pengukuran kinerja perusahaan dengan balance scorecard: bentuk, mekanisme, dan prospek aplikasinya pada BUMN. Jurnal Ekonomi dan Bisnis Indonesia 12(2).

Sulistyanto HS, Midiastuti PP. 2002. Seasoned Equity Offerings: Benarkah Underperformance Pasca Penawaran. Simposium Surviving Strategies to Cope With The Future; 2002 13-14 September; Yogyakarta; Indonesia. Yogyakarta: Universitas Atma Jaya.

Suratno IB. 2005. Economic value added: dari suatu alat penilaian kinerja manajemen menuju konsep pemerataan pendapatan. Jurnal Pendidikan Akuntansi Indonesia IV(2):133-154.

Tunggal AW. 2001. Economic Value Added (EVA): Teori, Soal, Kasus. Jakarta: Harvarindo.

Utomo LL. 1999. Economic value added sebagai ukuran keberhasilan kinerja manajemen perusahaan. Jurnal Akuntansi dan Keuangan 1(1):28-42.

Young SD, O’Byrne SF. 2000. EVA and Value-Based Management. New York: Mc-Graw Hill. 